\title{
Financial sector development and Investment in selected countries of the Economic Community of West African States: empirical evidence using heterogeneous panel data method
}

\author{
Chimere O. Iheonu ${ }^{1 *} \mathbb{D}$, Simplice A. Asongu², Kingsley O. Odo ${ }^{1}$ and Patrick K. Ojiem ${ }^{1}$
}

\author{
* Correspondence: iheonuchimere@ \\ yahoo.com \\ This study gives an empirical insight \\ to a theoretical suggestion that \\ financial sector development spur \\ investment. For the case of \\ ECOWAS, we have seen that \\ financial sector development \\ influence on investment is sensitive \\ to the indicator of financial sector \\ development. Empirical insight from \\ the study also revealed that the \\ impact of financial sector \\ development on investment is \\ different across the countries in \\ ECOWAS. This study therefore \\ provide policy recommendations \\ and implications which the \\ countries in ECOWAS must be \\ aware of. \\ 'Department of Economics, \\ University of Nigeria, Nsukka, \\ Nigeria \\ Full list of author information is \\ available at the end of the article
}

\section{Springer Open}

\begin{abstract}
This study investigated the impact of financial sector development on domestic investment in selected countries of the Economic Community of West African States (ECOWAS) for the years 1985-2017. The study employed the augmented mean group procedure, which accounts for country-specific heterogeneity and crosssectional dependence, and the Granger non-causality test to test for causality in the presence of cross-sectional dependence. The results show that (1) The impact of financial sector development on domestic investment depends on the measure of financial sector development utilised; (2) Domestic credit to the private sector has a positive but insignificant impact on domestic investment in ECOWAS, whereas banking intermediation efficiency (i.e., ability of the banks to transform deposits into credit) and broad money supply negatively and significant influence domestic investment; (3) Cross-country differences exist in the impact of financial sector development on domestic investment in the selected ECOWAS countries; and (4) Domestic credit to the private sector Granger causes domestic investment in ECOWAS. The study recommends careful consideration in the measure of financial development that is utilised as a policy instrument to foster domestic investment. We also highlight the importance of employing country-specific domestic investment policies to avoid blanket policy measures. Domestic credit to the private sector should be given priority when forecasting domestic investment into the future.
\end{abstract}

Keywords: Financial sector development, Domestic investment, Augmented mean group, Granger non-causality test, ECOWAS

JEL classification: $C 5, E 2, E 5$, GO

\section{Introduction}

The growth and development of every economy depends on the performance of various sectors of the economy. An important sector that contributes towards economic growth and development is the financial sector. Development of the financial sector

(c) The Author(s). 2020 Open Access This article is licensed under a Creative Commons Attribution 4.0 International License, which permits use, sharing, adaptation, distribution and reproduction in any medium or format, as long as you give appropriate credit to the original author(s) and the source, provide a link to the Creative Commons licence, and indicate if changes were made. The images or other third party material in this article are included in the article's Creative Commons licence, unless indicated otherwise in a credit line to the material. If material is not included in the article's Creative Commons licence and your intended use is not permitted by statutory regulation or exceeds the permitted use, you will need to obtain permission directly from the copyright holder. To view a copy of this licence, visit http://creativecommons.org/licenses/by/4.0/. 
enhances efficient access to financial services and products. Developments in the financial sector enable the flow of funds, which drives consumption and investment, thereby increasing employment, lifting individuals out of poverty, and thus improving economic performance (Tchamyou \& Asongu, 2017). An efficient intermediation process and improved financial sector increase the magnitude of domestic savings and boost the effectiveness of monetary policy in any nation or region by ensuring that scarce financial resources are channelled to the highest priority economic alternatives, outcomes and investments (Asongu \& Odhiambo, 2019; Tchamyou, 2020).

In the Economic Community of West African States (ECOWAS), the financial sector is still developing; its shortcomings are reflected in the difficulties faced by households and corporations to acquire credit. In fact, Alfaro et al. (2004) and Choong, Yusop and Soo (2004) have pointed out that inadequate development of the financial sector either in the market aspects or relating to institutions restricts the readiness of an economy to enjoy the benefits accruing from foreign direct investment (FDI) spillovers. The benefits of other forms of capital inflows can also be reduced as a result of an inadequate development in the financial sector.

Data for some selected ECOWAS member countries show substantial differences in the level of financial sector development as reflected by domestic credit to the private sector.

Of the seven countries shown in Fig. 1, the level of financial sector development in $\mathrm{Si}$ erra Leone can be seen to be relatively low compared to other ECOWAS countries. A similar case can also be said about Nigeria on the average. Compared to other emerging countries in Africa such as South Africa and Egypt, financial sector development in the ECOWAS is low. For example, between 2001 and 2017, domestic credit to the private sector as a percentage of GDP in Egypt averaged 37\%, whereas in South Africa it stood at $142 \%$. However, in Nigeria, domestic credit to the private sector as a percentage of GDP averaged 13.03\% between 2001 and 2017, and it was 4.85\% in Sierra Leone in that period.

The weaknesses in the financial sector in the ECOWAS could reflect the suboptimality of domestic investment levels and a poor general economic performance. Jalilian and Kirkpatrick (2007) and Odhiambo (2010) highlighted some benefits of a developed financial sector, such as facilitating domestic enterprises' access to local funds that will enable them to purchase new equipment, adopting advanced technology, attracting skilled labour, easing the credit constraint encountered by foreign companies and the ability to guide foreign direct investment in creating backward linkages with the rest of

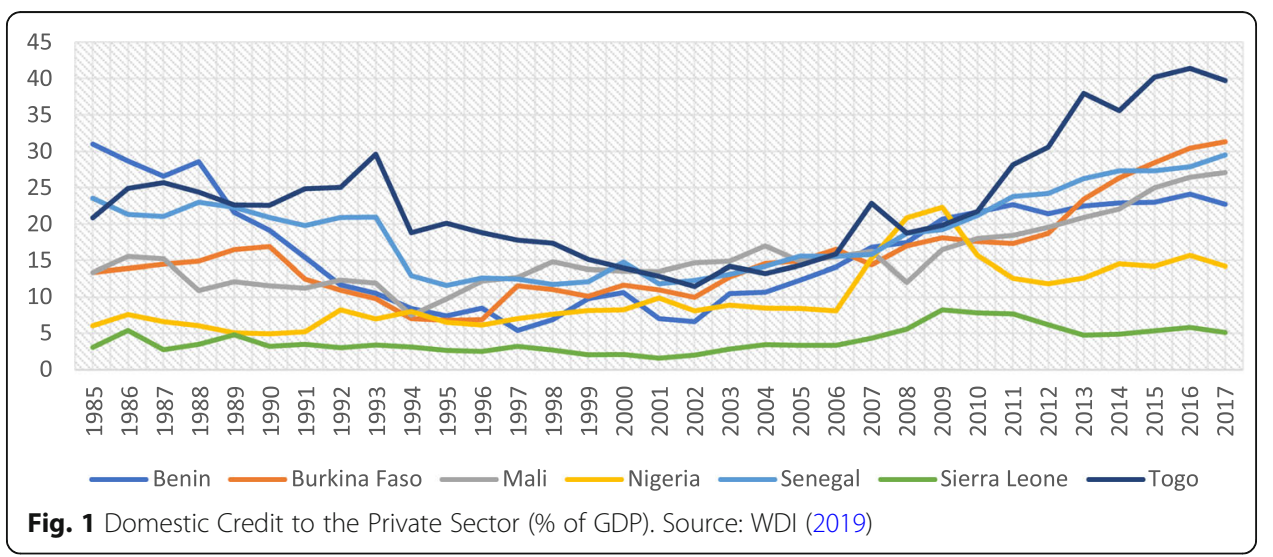


the economy. It is important to note that financial sector development is not only essential for investment in businesses but also has a positive impact on income distribution (Xu et al., 2003; Tchamyou, Erreygers \& Cassimon, 2019) by enabling the poor to invest in physical and human capital.

Contemporary growth theories (Kapur, 1976; Mathieson, 1979; Romer, 1986; Romer, 1990; Grossman \& Helpman, 1991; Pagano, 1993) have acknowledged the supportive role finance plays on the levels of capital accumulation and savings. Savings respond positively to variations in financial variables (Oyaromade, 2005) and influence the rate of technological development. Investment theories such as the Tobin Q theory and the Duesenberry (1958) financial theory of investment have also acknowledged the importance of financial sector development for new investment. Hamuda et al. (2013) reported that developed nations have accumulated a substantial level of investment over time. This is a clear indication of the key importance of increasing investment in the ECOWAS.

Although theoretical considerations suggest that financial sector development drives (domestic) investment, empirical evidence for the ECOWAS is sparse. Empirical research by Asare (2013) and Sakyi et al. (2016) has focused on the Ghanaian economy. However, our study is different from the highlighted studies, as it adopts a panel data procedure and thus accounts for more countries in the estimation procedure. The present research also departs from panel data studies of similar scope (e.g., Ndikumana, 2000; Misati \& Nyamongo, 2011) by utilising a more contemporary dataset and accounting for cross-sectional dependence as well as the long-run country-specific heterogeneity. It is helpful to have rich information on the interrelations among macroeconomic variables based on updated datasets to help policy-making decisions be made in an informed manner, especially including long-run cross-specific heterogeneities to derive more robust findings. The relevance of this study is also premised on the importance of investment in boosting economic activities that can lead to better living standards and lower poverty rates in the selected African countries. The African Development Bank (2018) has stated that the ECOWAS region has the highest number of countries where more than $30 \%$ of the population live on less than $\$ 1.90$ a day. Murthy and Soumya (2007) presented some arguments for the importance of investment on poverty reduction. The unfavourable economic conditions in ECOWAS countries have made it critical to identify key factors that can aid in the improvement of investment.

This study analyses financial sector development with the help of three different indicators to mitigate the potential issue of generalisation on the impact of financial sector development on domestic investment. This study captures financial sector development with (1) domestic credit to the private sector; (2) bank credit to bank deposit; and (3) broad money supply. The study also employs the augmented mean group (AMG) estimator, which is robust to the cross-sectional dependence that is likely to be significantly present in ECOWAS. The remainder of the paper presents a brief literature survey, the methodology and data employed, description and analysis of results and conclusions with relevant policy recommendations.

\section{Literature review}

Most studies on financial sector development have concentrated on its impact on economic growth. Some of these studies are Odeniran and Udeaja (2010); Esso (2010); 
Kar, Nazlioglu, and Agir (2011); Adusei (2013); Agbelenko and Kibet (2015); and Abubakar, Kassim and Yusoff (2015). Our study explores how financial sector development affects domestic investment. Similar to this study, Ndikumana (2000) evaluated the effect of financial sector development on domestic investment in 30 sub-Saharan African countries in a panel data framework. Empirical results from the dynamic serial correlation model indicated that there was a positive relationship between financial sector development and domestic investment in sub-Saharan Africa. Applying an extended simple accelerator model in a smaller sample of 18 sub-Saharan African countries, Misati and Nyamongo (2011) investigated the link between private investment and financial sector development using panel data from 1991 to 2004. They discovered that there is a negative relationship between the interest rate and private investment and indications of sizeable interest rate spreads in African economies. In addition, they also established that both credit to the private sector and the turnover ratio have substantial links with private investment, but the influence of turnover ratio on investment was inconsequential. The lack of significance of the stock market pointer reflects the low development of the stock market in most African economies.

The empirical evidence from a study by Asare (2013) utilising a three-stage least squares estimation technique for analysing the impact of financial liberalisation on private investment in Ghana from 1980 to 2007 suggested that the response of private investment to financial liberalisation is only marginal. In another similar study in Ghana, the autoregressive and distributed lag (ARDL) model was employed to examine the impact of financial sector development on private investment during 1970-2014. The findings showed that financial sector development has not been an important driver of private investment in the long run. However, in the short run, the effect of financial sector development on private investment is a function of the measure of financial sector development (Sakyi, Boachie \& Immurana, 2016). The ARDL model was also applied in the study of Muyambari (2017), who examined the association between financial sector development and investment in Botswana, South Africa and Mauritius from 1976 to 2014. The study grouped financial sector development into bank-based and market-based financial sector development. Country-specific results indicated that Botswana's bank-based financial sector development's impact on investment was positive in the short and long run. However, there was no impact of market-based financial sector development on investment. The investment impact of bank-based financial sector development in South Africa in the short term was identified to be negative but observed to have no impact in the long term. Mauritius' market-based financial sector development was the only type of financial sector development established to have a substantial beneficial effect on investment, and this was apparent for just the short term. Adopting the same ARDL model in addition to a trivariate Granger-causality technique on causal link between both bank-based and market-based financial sector development and investment from 1976 to 2014 revealed that in both models, bankbased and market-based financial sector development Granger cause investment in the short and long run (Muyambiri \& Odhiambo, 2018).

Asongu (2014) employed the vector autoregressive technique, the vector error correction model for the long-run and short-run effects and the Granger causality test to investigate the relationship between finance and investment (domestic, foreign, portfolio and total). To achieve this, the study introduced efficiency, activity and size, which were 
omitted in earlier studies, and maintained financial depth as had been used in other studies. The empirical result showed that finance-led investment elasticities are positive whereas investment elasticities are negative. Moreover, there was no sign of finance engendering portfolio investment in Guinea-Bissau, Mozambique and Togo, in contrast to the evidence in the previous literature. One of the policy implications of the result points to shortcomings in blanket policies that are not reliant on country-specific trends in the finance-investment nexus.

A structural model based on the Euler equation for investment was adopted by Love (2003) to evaluate how financial sector development and financing constraints impact growth through the efficiency of firm investment. They applied firm-level data from 40 nations. The outcome showed a strong negative link between the degree of financial market development and the responsiveness of investment to the availability of internal funds (a proxy for financing constraints). Other variables, such as size effect, business cycles and legal environment were considered and found to be plausible alternative explanations. Wurgler (2000) supported this and stated that financial sector development improves resource distribution and increases the efficiency with which investment funds are redistributed across businesses as demand differs.

This study adds to the literature by employing a more recent dataset for understanding how the financial sector affects domestic investment in selected ECOWAS countries. The study also accounts for the likelihood of cross-sectional dependence to avoid estimation bias. The reviewed previous panel data studies did not account for this issue.

\section{Methodology and data Methodology}

This study employs the augmented mean group (AMG) estimation procedure proposed by Eberhardt and Teal (2010), which is designed for a moderate number of cross sections and time periods (Nathaniel \& Iheonu, 2019; Iheonu \& Nwachukwu, 2020). The choice of the empirical strategy was motivated by contemporary studies on the consistency between an estimation technique and data behaviour (Kou, Lu, Peng \& Shi, 2012; Kou, Peng \& Wang, 2014; Kou, Ergu, Chen \& Lin, 2016; Kou, Yang, Xiao, Chen \& Alsaadi, 2019).

Bayar (2016) reported that the AMG procedure accounts for cross-sectional heterogeneity and thereby avoids blanket policy options by providing estimates for the individual countries. It also takes into account cross-sectional dependence in its estimation by including a common dynamic process in the modelling procedure. Oikarinen et al. (2018) explained that the inclusion of a common dynamic process is aimed at removing cross-sectional correlation through the identification of common trends triggered by unobservable factors. In this present study, the common dynamic process is implemented with a unit coefficient by subtracting it from the dependent variable. Dumitrescu and Hurlin (2012)'s Granger non-causality test was employed to ascertain whether financial sector development can be used to forecast domestic investment in the future. This is key in understanding future levels of domestic investment in ECOWAS. 
Prior to the estimation of our econometric model, we examined the statistical properties of the variables, beginning with the test for cross-sectional dependence. Crosssectional dependence entails correlation between error terms across cross sections (in this case, across ECOWAS countries). Iheonu (2019) and Iheonu et al. (2019) have reported that ignoring cross-sectional dependence can lead to estimation bias. The study employs four tests for cross-sectional dependence, namely the Breusch-Pagan Langragian Multiplier (LM) test, the Pesaran LM test, the bias-corrected scaled LM test and the Pesaran cross-sectional dependence (CD) test. These four tests are employed for robustness purposes. Also, four different panel unit root tests are employed in this study, encompassing both first-generation and second-generation unit root tests. They include the LLC unit root test of Levin, Lin and Chu (2002), the IPS unit root test proposed by Im, Pesaran and Shin (2003), and the PP-Fisher panel unit root test proposed by Maddala and Wu (1999) and Choi (2001). The study employs the second-generation unit root test of Pesaran (2007), known as the CIPS unit root test. While the firstgeneration unit root tests assume cross-sectional independence, the second-generation unit root test accounts for cross-sectional dependence. According to Iheonu, Ihedimma and Omenihu (2017) and Agbugba, Iheonu and Onyeaka (2018), the LLC test assumes that there is a common autoregressive parameter for all cross sections, whereas the IPS and PP-Fisher unit root tests assume a variation of the autoregressive parameters for all cross sections.

Our study then progresses to the test for long-run equilibrium in the model utilising four panel cointegration tests. They include the Pedroni $(1999,2004)$ cointegration test, the Kao (1999) cointegration test, the Johansen-Fisher cointegration test proposed by Maddala and Wu (1999) as well as the Westerlund panel cointegration test proposed by Westerlund (2007) and further developed by Persyn and Westerlund (2008). The Pedroni, Kao and Johansen-Fisher cointegration tests assume cross-sectional independence, whereas the Westerlund test accounts for cross-sectional dependence owing to the use of robust critical values through the process of bootstrapping.

This study draws from the financial theory of investment (Duesenberry, 1958), which recognises the role of the availability of funds when firms make investment decisions. As against the accelerator theory of investment that assumes that there are unlimited funds available to a firm, the financial theory of investment assumes that funds are limited and the demand for funds increases the cost of the corresponding funds. It is recognised from this theory that one of the mediums through which domestic investment can be improved is through the availability of funds as well as the ease of making the funds in the financial sector available to investors.

The study specifies an augmented mean group model where

$$
\begin{aligned}
& I_{i t}=\phi_{1} D C_{i t}+\phi_{2} B E_{i t}+\phi_{3} B M_{i t}+\phi_{4} G D P_{i t}+\phi_{5} R E M_{i t}+\varepsilon_{i t} \\
& \text { where } \varepsilon_{i t}=\tau_{1 i}+\lambda_{i} f_{t}+v_{i t}
\end{aligned}
$$

and $\phi_{1}, \phi_{2}, \phi_{3}, \phi_{4}$, and $\phi_{5}$ represent country-specific slope parameters. $\varepsilon_{i t}$ encompasses the unobservables and the error terms $v_{i t}$. The unobservables are made up of group fixed effects $\tau_{1 i}$ that capture the time-invariant heterogeneity across groups as well as an unobserved common factor $f_{t}$ with heterogeneous factor loadings $\lambda_{i}$, which captures 
time-invariant heterogeneity and cross-sectional dependence. This eliminated the effect of cross-sectional dependence in the estimation.

Here, $I$ is domestic investment; $D C$ is domestic credit; $B E$ is bank efficiency; $B M$ is broad money; GDP is GDP per capita, which is a proxy for economic growth and included in the model in line with the accelerator theory of investment; and REM is personal remittances. Studies by Dash (2020), Le (2018) and Yiheyis and Woldemariam (2015) have shown the importance of remittances to domestic investment.

\section{Data}

This study employs data for seven ECOWAS member countries for the period of 1985-2017. The choice of the dataset is guided by data availability and methodology constraints. Particularly, the cross-sectional Im Pesaran Shin (IPS) panel unit root test and the Westerlund (2007) panel cointegration test both require a balanced panel data. The study captures financial sector development utilising three measures, namely domestic credit to the private sector as a percentage of the GDP, bank credit to bank deposit (percentage) that according to the literature (Tchamyou, 2019; Asongu \& De Moor, 2017) measures banking intermediation efficiency, and broad money growth (annual percentage). Domestic credit to the private sector encompasses the financial resources provided to the private sector by financial corporations. Bank credit to bank deposit reflects the ability of banks to transform deposits into credit for households and economic operators (i.e., banking intermediation efficiency), and broad money captures the amount of money supply in an economy. It includes the highly liquid forms, which are also known as narrow money, and the less liquid forms.

Domestic investment is captured in the model by employing gross fixed capital formation in constant US\$ per capita. This measure is derived by dividing gross fixed capital formation by the total population of the individual countries under observation. The study utilises GDP per capita, constant US\$ and personal remittances (percent of GDP) as controls. For ease of interpretation, domestic investment and GDP per capita are converted to their natural logarithm. Table 1 summarises the variables employed in the econometric model.

The countries employed in the study were Benin, Burkina Faso, Mali, Nigeria, Senegal, Sierra Leone and Togo.

Table 1 Variables, descriptions and sources

\begin{tabular}{lll}
\hline Variables & Descriptions & Sources \\
\hline Domestic investment (I) & Gross fixed capital formation, constant US\$ per capita & WDI (2019) \\
Domestic credit (DC) & Domestic credit to the private Sector (percent of GDP) & WDI (2019) \\
Bank efficiency (BE) & Bank credit to bank deposit (percent) & GFDD (2019) \\
Broad money (BM) & Broad money growth (annual percent) & WDI (2019) \\
GDP per capita (GDP) & GDP per capita (constant US\$) & WDI (2019) \\
Personal remittances (REM) & Personal remittances (percent of GDP) & WDI (2019) \\
\hline
\end{tabular}

Source: Authors' compilation

Notes: WDI World Development Indicators; GFDD Global Financial Development Database 


\section{Presentation and analysis of results}

A brief description of the variables employed in the study is as follows. Table 2 describes the dataset. Table 2 first shows that there are 231 total observations. Table 2 also shows that the log of investment has an average value of 4.81, a minimum value of -0.1717 and a maximum value of 6.24 . This shows that there is substantial disparity between investments in the selected West African countries. However, this disparity is not as significant as that of the measures of financial sector development. The standard deviation of domestic credit, bank credit and broad money are 8.13, 33.46 and 17.28, respectively. This demonstrates a large variance of the observations across time.

GDP and remittances have an average value of 6.55 and 3.63, respectively, a minimum value of 5.61 and 0.003 , respectively, and a maximum value of 7.85 and 10.69 , respectively. The correlation among the variables in the model was also examined, with results revealing that the regressors are not near or perfectly correlated with each other. This reveals that the issue of multicollinearity is not a problem in our model. The result of the test for multicollinearity using the correlation matrix is available upon request.

Table 3 shows the result for the test for cross-sectional dependence. Based on the probability value, it is observed that three out of the four tests for cross-sectional dependence suggest its presence in the model at the $1 \%$ level of statistical significance, whereas the Pesaran CD test accepts the presence of cross-sectional dependence at the 10\% statistical significance level. However, the Pesaran CD test remains biased owing to the nature of the data (i.e. the longer time period relative to the number of cross sections).

The results of the cross-sectional dependence test validate the presence of crosssectional dependence among the variables in the model for the selected ECOWAS countries. This is plausible because of the level of economic integration among the countries in the region.

Regarding the test for unit root, results from Table 4, which provides the findings of the LLC and IPS unit root tests, show that for the LLC test, domestic investment is stationary only after first differencing under the intercept specification. However, under the intercept/trend specification, domestic investment is stationary in levels and also after first differencing. The IPS test result shows that domestic investment is stationary in both levels and after first differencing in both unit root specifications, that is, intercept and intercept/trend. In Table 4, domestic credit is stationary only after first difference, whereas bank credit and broad money are stationary in both levels and first difference under both intercept and intercept/trend specifications. GDP and remittance are stationary after first difference under both unit root tests and in both unit root specifications.

Table 2 Summary statistics of the variables

\begin{tabular}{llllll}
\hline Variables & Mean & Minimum & Maximum & Standard Deviation & Observations \\
\hline I & 4.8085 & -0.1717 & 6.2389 & 0.9417 & 231 \\
DC & 14.8534 & 1.6039 & 41.3981 & 8.1287 & 231 \\
$B E$ & 87.2221 & 20.9600 & 188.5900 & 33.4607 & 231 \\
$B M$ & 15.3219 & -18.0029 & 88.4006 & 17.2773 & 231 \\
GDP & 6.5449 & 5.6125 & 7.8489 & 0.5205 & 231 \\
REM & 3.6285 & 0.0035 & 10.6972 & 2.7201 & 231 \\
\hline
\end{tabular}

Source: Authors' compilation 
Table 3 Cross-sectional dependence tests

\begin{tabular}{lll}
\hline Tests & Statistics & Probability \\
\hline Breusch-Pagan LM & $84.3138^{* * *}$ & 0.0000 \\
Pesaran scaled LM & $8.6894^{* * *}$ & 0.0000 \\
Bias-corrected scaled LM & $8.5801^{* * *}$ & 0.0000 \\
Pesaran CD & $-1.8240^{*}$ & 0.0681 \\
\hline
\end{tabular}

Source: Authors' computation

Note: ${ }^{* * *}$ represents statistical significance at $1 \%$, * represents statistical significance at $10 \%$

Table 5 presents results from the PP-Fisher and CIPS unit root tests. The results show that domestic investment is stationary after first differencing in the PP-Fisher unit root test under the intercept specification, where domestic investment is stationary in both levels and after first difference under the intercept/trend specification for both unit root tests under consideration. Domestic credit under the PP-Fisher unit root test is stationary after first difference. It is however stationary in levels and after first difference under CIPS unit root test for the intercept specification. Domestic credit stationarity is achieved only after first difference for the intercept and trend specification. A similar result is also seen for bank credit apart from the CIPS unit root test under the intercept/trend specification, where bank credit is stationary in levels at the $10 \%$ statistical level and stationary at the $1 \%$ level after first differencing. Broad money is stationary both in levels and after first difference in both unit root tests and under both unit root specifications. GDP and REM are both stationary only after first difference in both unit root tests and under both unit root specifications.

These results, with particular consideration to the CIPS unit root test, show that all the variables are stationary at first difference. This implies that it is econometrically reasonable to test for a long-run relationship in the model. Table 6 presents results of the Pedroni cointegration test. The results reveals the presence of cointegration in the model as it can be seen that from the 11 statistics that encompass the withindimension and between-dimension, six statistics values support the presence of cointegration, and five reject the presence of cointegration.

This result is supported by both the Johansen-Fisher and Kao panel cointegration tests shown in Table 7. The results from the Johansen-Fisher cointegration test show that both the trace test and the maximum eigenvalue test reveal that there are at most four cointegrating equations within the model, suggesting the presence of

Table 4 Unit root tests results (a)

\begin{tabular}{|c|c|c|c|c|c|c|c|c|}
\hline \multirow[t]{3}{*}{ Variables } & \multicolumn{4}{|l|}{ LLC } & \multicolumn{4}{|l|}{ IPS } \\
\hline & \multicolumn{2}{|l|}{ Intercept } & \multicolumn{2}{|c|}{ Intercept and Trend } & \multicolumn{2}{|l|}{ Intercept } & \multicolumn{2}{|c|}{ Intercept and Trend } \\
\hline & Levels & First Diff. & Levels & First Diff. & Levels & First Diff. & Levels & First Diff. \\
\hline 1 & 0.4833 & $-6.3437^{* * *}$ & $-2.3018^{* *}$ & $-4.8848^{* * *}$ & 1.2259 & $-11.2513^{* * *}$ & $-2.8014^{* * *}$ & $-10.2442^{* * *}$ \\
\hline$D C$ & 2.009 & $-5.079 * * *$ & -0.701 & $-4.787^{* * *}$ & 2.678 & $-6.236^{* * *}$ & 1.258 & $-6.696^{* * *}$ \\
\hline$B E$ & $-3.824^{* * *}$ & $-6.544^{* * *}$ & $-2.039^{* *}$ & $-5.382^{* * *}$ & $-4.105^{* * *}$ & $-7.271^{* * *}$ & $-1.723^{* *}$ & $-6.236^{* * *}$ \\
\hline$B M$ & $-6.033^{* * *}$ & $-10.310^{* * *}$ & $-6.518^{* * *}$ & $-7.958^{* * *}$ & $-7.003^{* * *}$ & $-13.642^{* * *}$ & $-6.841^{* * *}$ & $-12.285^{* * *}$ \\
\hline GDP & 2.7422 & $-2.940^{* * *}$ & -0.690 & $-1.807^{* * *}$ & 4.371 & $-4.987^{* * *}$ & -0.070 & $-4.014^{* * *}$ \\
\hline REM & -0.7666 & $-6.6634^{* * *}$ & -1.2391 & $-8.0365^{* * *}$ & -0.4134 & $-5.5740^{* * *}$ & 0.3697 & $-6.8468^{* * *}$ \\
\hline
\end{tabular}

Source: Authors' computation

Note: ** and ** represent statistical significance at $1 \%$ and $5 \%$, respectively. I domestic investment, DC domestic credit, $B E$ bank Efficiency (credit/deposit), BM broad money, GDP gross domestic product, REM remittances. First Diff First difference 
Table 5 Unit root test results (b)

\begin{tabular}{|c|c|c|c|c|c|c|c|c|}
\hline \multirow[t]{3}{*}{ Variables } & \multicolumn{4}{|l|}{$\mathrm{PP}$} & \multicolumn{4}{|l|}{ CIPS } \\
\hline & \multicolumn{2}{|l|}{ Intercept } & \multicolumn{2}{|c|}{ Intercept and Trend } & \multicolumn{2}{|l|}{ Intercept } & \multicolumn{2}{|c|}{ Intercept and Trend } \\
\hline & Levels & First Diff. & Levels & First Diff. & Levels & First Diff. & Levels & First Diff. \\
\hline 1 & 13.0770 & $187.717^{* * *}$ & $38.1283^{* * *}$ & $358.277^{* * *}$ & $-2.094^{*}$ & $-5.610^{* * *}$ & $-3.295^{* * *}$ & $-5.830^{* * *}$ \\
\hline$D C$ & 5.577 & $128.565^{* * *}$ & 4.0794 & $133.762^{* * *}$ & $-2.229^{* *}$ & $-5.427^{* * *}$ & -2.291 & $-5.458^{* * *}$ \\
\hline$B E$ & 18.322 & $59.9117^{* * *}$ & 5.7203 & $54.077^{* * *}$ & $-2.589^{* * *}$ & $-3.796^{* * *}$ & $-2.790^{*}$ & $-3.697^{* * *}$ \\
\hline$B M$ & $111.686^{* * *}$ & $174.996^{* * *}$ & $171.231^{* * *}$ & $1611.05^{* * *}$ & $-3.636^{* * *}$ & $-5.958^{* * *}$ & $-4.258^{* * *}$ & $-6.158^{* * *}$ \\
\hline GDP & 2.431 & $134.846^{* * *}$ & 17.736 & $127.771^{* * *}$ & -1.231 & $-5.693^{* * *}$ & -2.354 & $-5.870^{* * *}$ \\
\hline REM & 14.7125 & $164.564^{* * *}$ & 15.2725 & $518.488^{* * *}$ & -1.319 & $-5.933^{* * *}$ & -2.455 & $-5.997^{* * *}$ \\
\hline
\end{tabular}

Source: Authors' computation

Note: ${ }^{* *},{ }^{* *}$ and ${ }^{*}$ represent statistical significance at $1 \%, 5 \%$ and $10 \%$, respectively. I domestic investment, DC domestic credit, $B E$ bank efficiency (credit/deposit), BM broad money, GDP gross domestic product, REM remittances, First Diff First difference

cointegration. The result from the Kao test shows that the ADF t-statistic is significant at the $1 \%$ significance level, suggesting a strong presence of cointegration.

The results from the Westerlund cointegration test in Table 8 provide four panel cointegration test results. Gt and Ga represent the group mean tests, and Pa and Pt are a representation of the panel mean test that pools information over all cross-sectional units and tests for cointegration for the panel as a whole.

The results show the presence of cointegration even after accounting for crosssectional dependence, as can be observed from the robust $p$-values for all four tests that are statistically significant. The results of the cointegration tests suggest that our model can be estimated by employing the AMG, which is robust to cross-sectional dependence.

The results from Table 9 show that for the whole panel denoted as full, domestic credit has a positive but insignificant impact on domestic investment in ECOWAS. The positive relationship is in line with the financial theory of investment. However, banking efficiency and broad money significantly reduce domestic investment in ECOWAS. Furthermore, GDP significantly increases domestic investment. The study did not find any significant relationship between remittances and domestic investment in ECOWAS.

Country-specific results show that in Benin, GDP significantly improves domestic investment, and remittances improve domestic investment although insignificantly. The study did not find any significant relationship between the measures of financial development and domestic investment. Further, in Burkina Faso and Nigeria, financial sector development did not have a significant influence on domestic investment. In Mali,

Table 6 Panel cointegration test (Pedroni)

\begin{tabular}{llll}
\hline Statistics & \multicolumn{2}{l}{ Within-Dimension (Panel) } & \multicolumn{2}{l}{$\begin{array}{c}\text { Between-Dimension (Group) } \\
\text { Statistics }\end{array}$} \\
\cline { 2 - 3 } & Statics & Weighted Statistics & \\
\hline V-Statistic & -1.9183 & -0.9060 & 0.6765 \\
Rho-Statistic & 2.1301 & 0.0997 & $-5.3958^{* * *}$ \\
PP-Statistic & $-5.5956^{* * *}$ & $-4.0487^{* * *}$ & $-1.5060^{*}$ \\
ADF-Statistic & $-6.3521^{* * *}$ & $-1.7493^{* *}$ & \\
\hline
\end{tabular}

Source: Authors' computation

Note: ${ }^{* *},{ }^{* *}$ and ${ }^{*}$ represent statistical significance at the $1 \%, 5 \%$ and $10 \%$ statistical levels, respectively. Trend assumption: deterministic intercept and trend 
Table 7 Panel cointegration test (Johansen-Fisher and Kao)

\begin{tabular}{lll}
\hline Panel A: Johansen-Fisher & & \\
\hline Hypothesised No. of CE(s) & Fisher Stat (Trace Test) & Fisher Stat (Maximum Eigen Test) \\
\hline None & $211.3^{* * *}$ & $109.5^{* * *}$ \\
At most 1 & $121.0^{* * *}$ & $67.10^{* * *}$ \\
At most 2 & $64.83^{* * *}$ & $44.60^{* * *}$ \\
At most 3 & $31.69^{* * *}$ & $26.16^{* *}$ \\
At most 4 & 16.07 & 16.32 \\
At most 5 & 13.23 & 13.23 \\
Panel B: Kao & & \\
ADF t-Statistic & & P-value \\
$-3.4409^{* * *}$ & & 0.0003
\end{tabular}

Source: Authors' computation

Note: ${ }^{* *}$ and ${ }^{* *}$ represent statistical significance at $1 \%$ and $5 \%$, respectively. Null hypothesis/trend assumption in Kao: no cointegration/no deterministic trend. Trend assumption in Johansen-Fisher: linear deterministic trend

however, broad money reduced domestic investment significantly. Banking efficiency significantly reduced domestic investment in Senegal, and domestic credit to the private sector increased domestic investment significantly in Sierra Leone and Togo, with broad money reducing domestic investment significantly in both countries.

In Burkina Faso, Mali, Senegal, Sierra Leone and Togo, GDP acts as a significant factor contributing to long-run domestic investment. Remittances contribute substantially to domestic investment in Burkina Faso and Togo. This is in line with the findings of Dash (2020) and Le (2018). In Senegal, remittances reduce domestic investment significantly.

In summary, results from the Dumitrescu and Hurlin Granger non-causality test as revealed in Table 10 show that domestic credit to the private sector Granger causes domestic investment in ECOWAS. Bank efficiency and broad money do not Granger cause domestic investment in ECOWAS as indicated by their insignificant p-values. We also found that GDP Granger causes domestic investment in ECOWAS but remittances do not. This implies that present values of domestic credit and GDP can be utilised to forecast future values of domestic investment in the sub-region.

\section{Conclusions, policy recommendations and future research directions}

This study investigated the impact of financial sector development on domestic investment in the ECOWAS between 1985 and 2017. The study employed domestic credit to the private sector, bank credit-to-bank deposit (i.e., banking intermediation efficiency) and broad money as indicators of financial sector development. The study used the AMG estimation procedure that has the advantage of producing country-specific

Table 8 Panel cointegration tests (Westerlund)

\begin{tabular}{lllll}
\hline Statistic & Value & Z-value & P-value & Robust $P$-value \\
\hline Gt & -2.748 & -1.428 & 0.077 & 0.030 \\
Ga & -13.514 & -0.617 & 0.269 & 0.000 \\
Pt & -10.865 & -4.817 & 0.000 & 0.010 \\
Pa & -25.236 & -5.724 & 0.000 & 0.000 \\
\hline
\end{tabular}

Source: Authors' computation

Note: Null hypothesis was no cointegration. Gt and Ga represent group mean tests; Pa and Pt are the panel mean tests 


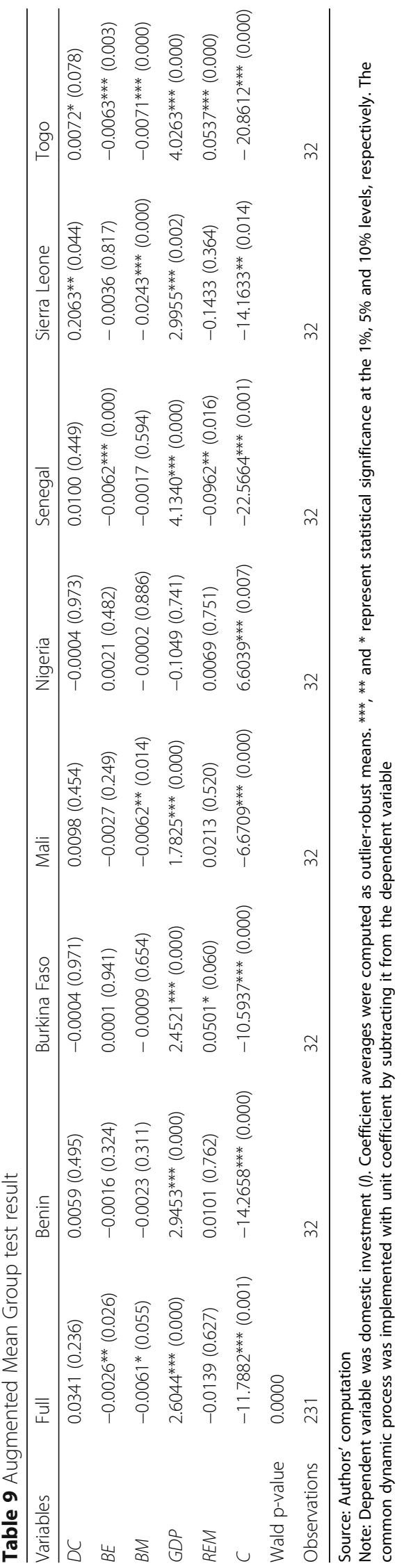


Table 10 Dumitrescu and Hurlin (2012) Granger non-causality test

\begin{tabular}{llll}
\hline Null Hypothesis & W-bar & Z-bar & Probability \\
\hline$D C \neq>1$ & 3.5726 & 4.8129 & 0.0200 \\
$B E \neq>1$ & 1.2290 & 0.4283 & 0.7600 \\
$B M \neq>1$ & 1.3615 & 0.6762 & 0.5200 \\
$G D P \neq 1$ & 6.3084 & 9.9312 & 0.0000 \\
$R E M \neq>1$ & 2.6061 & 3.0047 & 0.1400 \\
\hline
\end{tabular}

Source: Authors' computation

Note: Lag order was 4 . Probability values were computed using 100 bootstrap replication. The symbol $\neq>$ represents no causality between the selected variables. $D C$ domestic credit, I domestic investment, $B E$ bank efficiency, $B M$ broad money, REM remittances

results as well as an overall estimate for the panel (i.e. the ECOWAS) while still accounting for cross-sectional dependence. The empirical results showed that the impact of financial sector development on domestic investment depends on the indicator of financial sector development. The overall result for the region indicated that bank efficiency and broad money significantly reduce the level of domestic investment in the long run while domestic credit improves domestic investment, however, insignificantly. GDP is also essential for increasing domestic investment in the sub-region. However, country-specific results show significant disparities in the relationship between financial sector development and domestic investment. Furthermore, results from the Granger non-causality test revealed that domestic credit to the private sector and GDP can be utilised to forecast future values of domestic investment in ECOWAS. Based on these findings, the following recommendations are reasonable: (1) Policy-makers should be cautious of the measures of financial sector development that are employed as policy instruments to foster domestic investment in the ECOWAS; (2) Because of the heterogeneous nature of the findings pertaining to the countries of the subregion, individual domestic investment policies should be employed in order to avoid blanket domestic investment policies; (3) Policy-makers should also aim at improving economic growth in the ECOWAS; and (4) Domestic credit to the private sector and GDP should be given utmost importance in future domestic investment forecasting.

The fact that banking intermediation efficiency significantly reduces domestic investment is not consistent with the studies of Fouda (2009) and Asongu (2014). These studies did not find a significant relation between banking intermediation efficiency and domestic investment. The potential reasons could be that Fouda (2009) concentrated on the Central African Economic and Monetary Community, and Asongu (2014) employed time series methodologies with data ending in 2008. One of the major reasons for economic slowness is the inability of banks to transform mobilised deposits into credit for corporations and households. Further, bottlenecks and inefficiencies in the banking system in these West African countries may impede credit to corporations and households. As a future research direction, repositioning this study in the context of the potential West African Monetary Zone is timely given that the proposed ECO (ECOWAS common currency) is to be launched in 2020.

Acknowledgements

Not applicable.

Authors' contributions

All author's contributed equally to the research article. The author(s) read and approved the final manuscript. 
Funding

There is no funding for this research.

\section{Availability of data and materials}

The dataset used during the study are available from the corresponding author on reasonable request.

\section{Competing interests}

The author's declare that they have no competing interests.

\section{Author details}

'Department of Economics, University of Nigeria, Nsukka, Nigeria. ${ }^{2}$ Department of Economics, University of South Africa, P. O. Box 392, UNISA, Pretoria 0003, South Africa.

Received: 12 November 2019 Accepted: 18 August 2020

Published online: 31 August 2020

\section{References}

Abubakar A, Kassim SH, Yusoff MB (2015) Financial development, human capital accumulation and economic growth: empirical evidence from the economic Community of West African States (ECOWAS). Procedia Soc Behav Sci 172:96-10 Adusei M (2013) Financial development and economic growth: evidence from Ghana. Int J Business Finance Res 7(5):61-76 African Development Bank (2018) West Africa economic outlook 2018. Africa development Bank Group. Retrieved from www. afdb.org/fileadmin/uploads/afdb/Documents/Publications/2018AEO/African_Economic_Outlook_2018_West_Africa.pdf

Agbélénko FA, Kibet KS (2015) Financial development and economic growth in west African economic and monetary union (WAEMU). Afr J Bus Manag 9(17):624-632

Agbugba I, Iheonu C, Onyeaka K (2018) Homogeneous and heterogeneous effect of exchange rate on economic growth in African countries. Int J Econ Commerce Manag 6(9):1-14

Alfaro L, Chanda A, Kalemli-Ozcan S, Sayek S (2004) FDI and economic growth: the role of local financial markets. J Int Econ 64(1):89-112

Asare E (2013) The impact of financial liberalization on private investment in Ghana. Int J Business Finance Res 7(4):77-90

Asongu S (2014) Linkages between investment flows and financial development: causality evidence from selected African countries. Afr J Econ Manag Stud 5(3):269-299

Asongu SA, De Moor L (2017) Financial globalisation dynamic thresholds for financial development: evidence from Africa. Eur J Dev Res 29(1):192-212

Asongu SA, Odhiambo MN (2019) Challenges to doing business in Africa: a systematic review. J Afr Bus 20(2):259-268

Bayar Y (2016) Financial development and unemployment in emerging market economies. Scientific Ann Economics Business 63(2):237-245

Choi I (2001) Unit root tests for panel data. J Int Money Financ 20(2):249-272

Choong CK, Yusop Z, Soo SC (2004) Foreign direct investment, economic growth, and financial sector development: a comparative analysis. ASEAN Econ Bull 21(3):278-289

Dash R (2020) Impact of remittances on domestic investment: a panel study of six south Asian countries. South Asia Economic Journal. https://doi.org/10.1177/1391561420903199

Duesenberry J (1958) Business cycles and economic growth. McGraw-Hill, New York

Dumitrescu E, Hurlin C (2012) Testing for granger non-causality in heterogeneous panels. Econ Model 46(1):1450-1460

Eberhardt M, Teal F (2010) Productivity analysis in global manufacturing production. Department of Economics, University of Oxford, discussion paper 515. Retrieved from www.economics.ox.ac.uk/research/WP/pdf/paper515.pdf

Esso LJ (2010) Re-examining the finance-growth nexus: structural break, threshold cointegration and causality evidence from the Ecowas. J Econ Dev 35(3)

Fouda OJP (2009) The excess liquidity of banks in the Franc zone: how to explain the paradox in the CEMAC. Revue Africaine de l'Integration 3(2):1-56.

Global Financial Development (2019). Global Financial Development Database. Washington, DC: The World Bank.

Grossman GM, Helpman E (1991) Innovation and growth in the global economy. MIT press

Hamuda AM, Šuliková V, Gazda V, Horváth D (2013) ARDL investment model of Tunisia. Theoretical Applied Economics 20(2) Iheonu C (2019) Governance and domestic investment in Africa. European Journal of Government and Economics 8(1):63-80

Iheonu C, Agbutun S, Omenihu C, Ihedimma G, Osuagwu V (2019) The impact of governance quality on mortality rates in sub Saharan Africa. Afr Popul Stud 33(1):4655-4668

Iheonu C, Ihedimma G, Omenihu M (2017) A pooled mean group estimation of capital inflow and economic growth in sub Saharan Africa. Romanian Economic J 20(65):105-121

Iheonu C, Nwachukwu T (2020) Macroeconomic determinants of household consumption in selected west African countries. Econ Bull 40(2):1596-1606

Im K, Pesaran M, Shin Y (2003) Testing for unit roots in heterogeneous panels. J Econ 115:53-74

Jalilian H, Kirkpatrick C, Parker D (2007) The impact of regulation on economic growth in developing countries: a crosscountry analysis. World Dev 35(1):87-103

Kao C (1999) Spurious regression and residual based tests for cointegration in panel data. J Econ 90(1):1-44

Kapur BK (1976) Alternative stabilization policies for less-developed economies. Journal of political economy 84(4, part 1):777-795

Kar M, Nazlıoglu ş, Ağır H (2011) Financial development and economic growth nexus in the MENA countries: bootstrap panel granger causality analysis. Econ Model 28(1-2):685-693

Kou G, Ergu D, Chen Y, Lin C (2016) Pairwise comparison matrix in multiple criteria decision making. Technol Econ Dev Econ 22(5):738-765

Kou G, Lu Y, Peng Y, Shi Y (2012) Evaluation of classification algorithms using MCDM and rank correlation. Int J Information Technology Decision Making 11(1):197-225 
Kou G, Peng Y, Wang G (2014) Evaluation of clustering algorithms for financial risk analysis using MCDM methods. Inf Sci 275(August):1-12

Kou G, Yang P, Xiao F, Chen Y, Alsaadi FE (2019) Evaluation of feature selection methods for text classification with small datasets using multiple criteria decisionmaking methods. Appl Soft Comput. https://doi.org/10.1016/j.asoc.2019.105836

Le T (2018) The impact of remittances on domestic investment in developing countries: fresh evidence from the Asia-Pacific region. Organisations and Markets in Emerging Economies 9(2)

Levin A, Lin C, Chu C (2002) Unit root tests in panel data: asymptotic and finite sample properties. J Econ 108:1-24

Love I (2003) Financial development and financing constraints: international evidence from the structural investment model. Rev Financ Stud 16(3):765-791

Maddala G, Wu S (1999) A comparative study of unit root tests with panel data and a new simple test. Oxf Bull Econ Stat 61(0):631-652

Mathieson DJ (1979) Financial reform and capital flows in a developing economy. Staff Papers 26(3):450-489

Misati RN, Nyamongo EM (2011) Financial development and private investment in sub-Saharan Africa. J Econ Bus 63(2):139-151

Murty K, Soumya A (2007) Effects of public investment on growth and poverty. Econ Polit Wkly 42(1):47-59

Muyambiri B (2017) The financial development and investment nexus: empirical evidence from three southern African countries (doctoral dissertation)

Muyambiri B, Odhiambo NM (2018) The causal relationship between financial development and investment: a review of related empirical literature. Comp Econ Res 21(2):119-136

Nathaniel S, Iheonu C (2019) Carbon dioxide abatement in Africa: the role of renewable and non-renewable energy consumption. Sci Total Environ 679:337-345

Ndikumana L (2000) Financial determinants of domestic investment in sub-Saharan Africa: evidence from panel data. World Dev 28(2):381-400

Odeniran SO, Udeaja EA (2010) Financial sector development and economic growth: empirical evidence from Nigeria. Econ Financial Rev 48(3):91-124

Odhiambo NM (2010) Finance-investment-growth nexus in South Africa: an ARDL-bounds testing procedure. Econ Chang Restruct 43(3):205-219

Oikarinen E, Bourassa S, Hoesli M, Engblom J (2018) U.S. metropolitan house price dynamics. J Urban Econ 105(C):54-69

Oyaromade R (2005) Financial sector reforms and financial savings in Nigeria. In: Selected papers for the Nigerian economic society conference, pp 427-448

Pagano M (1993) Financial markets and growth: an overview. Eur Econ Rev 37(2-3):613-622

Pedroni P (1999) Critical values for cointegration tests in heterogeneous panels with multiple regressors. Department of Economics Working Papers 2000-02

Pedroni P (2004) Panel cointegration: asymtotic and finite sample properties of pooled time series tests with an application to the PPP hypothesis. Econometric Theory 20:597-625

Persyn D, Westerlund J (2008) Error-correction-based cointegration tests for panel data. Stata J 8(2):232-241

Pesaran M (2007) A simple unit root test in the presence of cross-section dependence. J Appl Econ 22(2):265-312

Romer PM (1986) Increasing returns and long-run growth. J Polit Econ 94(5):1002-1037

Romer PM (1990) Endogenous technological change. Journal of political economy 98(5, part 2): S71-S102

Sakyi D, Boachie M, Immurana M (2016) Does financial development drive private investment in Ghana? Economies 4(27)

Tchamyou VS (2019) The role of information sharing in modulating the effect of financial access on inequality. J Afr Bus 20(3): $317-338$

Tchamyou VS (2020) Education, lifelong learning, inequality and financial access: evidence from African countries. Contemp Soc Sci 15(1):7-25

Tchamyou VS, Asongu SA (2017) Information sharing and financial sector development in Africa. J Afr Bus 18(7):24-49

Tchamyou VS, Erreygers G, Cassimon D (2019) Inequality, ICT and financial access in Africa. Technol Forecast Soc Chang 139(February):169-184

Westerlund J (2007) Testing for error correction in panel data. Oxf Bull Econ Stat 69(6):709-748

World Development Indicators (2019). World Bank World Development Indicators database. Washington, DC: The World Bank

Wurgler J (2000) Financial markets and the allocation of capital. J Financ Econ 58(1-2):187-214

Xu L, Clarke G, Zou H (2003) Finance and income inequality. Policy research working paper series 2984

Yiheyis Z, Woldemariam K (2015) The effect of remittances on domestic capital formation in selected African countries: a comparative empirical analysis. J Int Dev 28(2):243-265

\section{Publisher's Note}

Springer Nature remains neutral with regard to jurisdictional claims in published maps and institutional affiliations. 